\title{
EVALUASI PROGRAM PEMBERDAYAAN USAHA AGRIBISNIS PERDESAAN (PUAP) PROVINSI DAERAH ISTIMEWA YOGYAKARTA
}

\author{
Agus Dwi Nugroho, Lestari Rahayu Waluyati, dan Jamhari \\ Fakultas Pertanian Univesitas Gadjah Mada \\ Email: agus.dwi.n@mail.ugm.ac.id
}

\begin{abstract}
Rural Agribusiness Enterpreneurship Empowerment (RAEE) not only has a beneficial impact for the farmers, but also has many problems. This research was intended 1) to know the performance of RAEE; 2) to know the effectiveness of RAEE on community income and its determining factors; 3) to know the performance and efficiency of Agribusiness Micro Financing Institute (AMFI) and its determining factors. The study was carried out from March until April 2013 in Bantul, Gunungkidul, Kulon Progo, and Sleman Regencies. The respondents were 60 AMFIs and 120 member farmers. RAEE can increase farmer's income; reduce the number of poor people; increase the number of members, savings, and assets of the combined farmer groups; increase employment, and encourage farmers not to lend to other institutions. But, RAEE also has problems, including deviation of the distribution of RAEE funds, inappropriate use of RAEE funds regard to the planning, problems of bad loans, unofficial legality of most of the AMFIs, and the low capacity of human resources manager. The determinant factors of the RAEE effectiveness are the length of the loan and the type of business. Most of the AMFI in DIY performs poorly. The determinant factors of the AMFI efficiency are the amount of independent capital and the presence of mentoring. The steps to improve RAEE include coaching and supervision of AMFI, control of bad loans, selecting the business types of AMFI, and encouraging AMFI to become an official legal entity.
\end{abstract}

Keywords: Amfi; Efectiveness; Efficiency; RAEE; Gapoktan.

\begin{abstract}
ABSTRAK
Program Pemberdayaan Usaha Agribisnis Perdesaan (PUAP) tidak hanya menguntungkan bagi petani, tetapijuga memiliki banyak masalah. Penelitian ini bermaksud1) untuk mengetahui implementasi PUAP;2) mengetahui efektivitas PUAP bagi perubahan pendapatan masyarakat dan faktor yang memengaruhinya; 3) mengetahui kinerja dan efisiensi LKM-A serta faktor yang memengaruhinya. Penelitian dilaksanakan Maret sampai April 2013 di Kabupaten Bantul, Gunungkidul, Kulon Progo, dan Sleman. Sampel penelitian ini yakni 60 pengurus LKM-A dan 120 petani anggota. PUAP mampu meningkatkan pendapatan petani; mengurangi jumlah penduduk miskin; meningkatkan jumlah anggota, simpanan, dan aset gapoktan; meningkatkan lapangan kerja dan mendorong petani untuk tidak meminjam dana ke lembaga lain. Akan tetapi, PUAP juga mengalami masalah, diantaranya penyimpangan penyaluran dana PUAP, penggunaan dana PUAP tidak sesuai rencana, kredit macet, sebagian besar LKM-A belum berbadan hukum serta kapasitas SDM pengelola masih rendah. Faktor penentu efektivitas program PUAP yaitu lama pinjaman dan jenis usaha. Sebagian besar LKM-A di DIY berkinerja kurang baik. Faktor penentu efisiensi LKM-A adalah jumlah modal mandiri dan adanya pendampingan. Langkah untuk perbaikan PUAP antara lain pengawasan dan pendampingan LKM-A; pengendalian kredit macet; pemilihan jenis usaha LKM-A, dan pendorongan LKMA untuk menjadi lembaga yang berbadan hukum.
\end{abstract}

Kata kunci: Efektivitas; Efisiensi; LKM-A; Puap; Gapoktan. 


\section{PENGANTAR}

Petani sering menghadapi masalah di antaranya tidak mampu mengakses permodalan sehingga sering menggunakan pinjaman yang tidak menguntungkan (Supanggih dan Widodo, 2013). Dampak dari masalah ini adalah petani tidak mampu menjamin keberlangsungan usahataninya (Rahayu, 2015). Masalah ini sebenarnya juga muncul karena rendahnya perhatian perbankan terhadap sektor pertanian. Pertanian diasumsikan memiliki risiko tinggi (high risk) dengan perputaran dana yang lambat sehingga menghambat akses petani ke perbankan (Iski $d k k$., 2016).

Pemerintah berusaha mengatasi masalah ini melalui program Pengembangan Usaha Agribisnis Perdesaan (PUAP) dengan memberikan bantuan modal sebesar Rp100 juta untuk tiap Gabungan Kelompok Tani (Gapoktan). Program ini memberikan modal usaha bagi petani, baik pemilik atau penggarap lahan serta buruh tani (Supriatna, 2012).

PUAP mulai dilaksanakan pada tahun 2008. Pada awalnya PUAP disalurkan bagi 389 Kabupaten/Kota (10.542 gapoktan), dan terus meningkat hingga pada tahun 2011 digulirkan untuk 445 Kabupaten/Kota (9.110 gapoktan) (Dwimanur dan Wibowo, 2014). Pemerintah berharap dana tersebut dapat berkembang melalui Unit Usaha Simpan Pinjam (USP) pada tahun pertama yang selanjutnya berkembang menjadi Lembaga Keuangan Mikro Agribisnis (LKM-A) pada tahun kedua dan koperasi pada tahun ketiga (Utami, 2015).

Hasil penelitian menunjukkan LKM-A penerima PUAP akan semakin efisien atau baik apabila dikelola oleh manajer yang berpendidikan tinggi, umur LKM-A yang semakin besar sehingga pengelolaan LKM-A semakin profesional, jumlah hari pelayanan LKM-A yang banyak setiap tahunnya, dan jumlah pengelola LKM-A yang sedikit (Saleh dkk, 2012).

Efektivitas kredit akan meningkat apabila cepatnya persetujuan mendapat dana pinjaman, cepatnya penurunan dana pinjaman, pendidikan peminjam yang tinggi, jumlah modal yang dialokasikan cukup besar, dan jenis usaha peminjam (Rahayuningsih, 2013; Ismanto dan Diman, 2014).

Program PUAP memiliki dampak sosial berupa bertambahnya wawasan petani tentang simpan-pinjam di Gapoktan dan meningkatnya interaksi antar petani, sedangkan dari sisi ekonomi, dampak program ini yakni petani dapat memperoleh pinjaman dengan prosedur dan syarat yang mudah, petani tidak terikat lagi kepada tengkulak serta pendapatan petani dan kesempatan kerja juga akan meningkat (Martiana dkk., 2012; Suandi dkk., 2012; Erna dkk., 2014). Akan tetapi, banyak pula gapoktan yang gagal mengembangkan dana PUAP karena kapasitas SDM tidak mampu mengelola dana serapan dan perputaran dana PUAP rendah, ada petani yang terlambat bahkan tidak mengembalikan dana serta penyimpangan penggunaan dana untuk aktivitas konsumtif (Pangestika dkk., 2013; Supardi dkk., 2015; Zanzes dkk., 2015).

Penerima PUAP di Provinsi Daerah Istimewa Yogyakarta juga diduga menghadapi masalah yang sama. Jumlah gapoktan penerima dana di DIY dari tahun 2008-2012 ada 435 unit. Penelitian ini menjadi penting karena dana PUAP tahun 2012 di DIY merupakan tahun pemberian dana dari Kementerian Pertanian dan selanjutnya Pemerintah DIY berencana melanjutkan pengelolaan LKM-A dan memberikan bantuan dana semacam PUAP bagi gapoktan.

Dengan begitu sangat menarik untuk dilakukan kajian dengan tujuan (1) mengetahui implementasi PUAP; (2) mengetahui efektivitas PUAP bagi perubahan pendapatan masyarakat dan faktor yang mempengaruhinya; (3) mengetahui kinerja dan efisiensi LKM-A serta faktor yang mempengaruhinya.

Kegiatan penelitian ini dilaksanakan di empat kabupaten, yaitu Kabupaten Bantul, Gunungkidul, Kulon Progo, dan Sleman selama dua bulan, yaituMaret sampai dengan April 2013. Sampel penelitian ini adalah 60 pengelola PUAP pada empat kabupaten di DIY. Metode yang digunakan untuk memilih responden adalah proportional random sampling, yaitu pada setiap kabupaten dipilih sebanyak $30 \%$ gapoktan dari seluruh gapoktan penerima 
PUAP. Jumlah responden Kabupaten Bantul, Kulon Progo, dan Gunungkidul yaitu 18 gapoktan perkabupaten serta untuk wilayah Sleman adalah enam responden. Selanjutnya wawancara juga dilakukan terhadap dua petani anggota tiap gapoktan atau total 120 petani. Metode untuk memilih Gapoktan dan petani tiap kabupaten adalah metode acak (random).

Tabel 1

Sampel LKM-A Penelitian Berdasarkan Tahun Anggaran

\begin{tabular}{|c|c|c|c|c|c|}
\hline \multirow[t]{2}{*}{ No } & \multirow[t]{2}{*}{ Kabupaten } & \multicolumn{4}{|c|}{ Tahun Anggaran } \\
\hline & & 2008 & 2009 & & 2011 \\
\hline 1 & Bantul & 6 & 4 & 4 & \\
\hline 2 & Kulon Progo & 4 & 3 & 8 & \\
\hline 3 & Gunungkidul & 2 & 4 & 3 & \\
\hline 4 & Sleman & 3 & 3 & 0 & \\
\hline \multicolumn{2}{|c|}{ Jumlah } & 15 & 14 & 15 & \\
\hline
\end{tabular}

Metode analisis yang digunakan, yaitu (1) Untuk mengetahui implementasi PUAP maka dilakukan analisis kualitatif berdasarkan wawancara dengan dinas pertanian, pengelola serta responden petani penerima program; (2) Untuk mengetahui efektivitas program dapat didekati dengan melihat persentase perubahan pendapatan penerima program, sedangkan analisis regresi berganda digunakan untuk menentukan faktor yang berpengaruh terhadap tingkat efektivitas program; (3) Untuk mengetahui kinerja LKM-A Gapoktan di DIY, digunakan metode skoring berdasarkan hasil wawancara pengelola. Menurut Saleh dkk., (2012), evaluasi kinerja pelaksanaan program PUAP ditinjau dari lima indikator yaitu input (masukan), process (proses), output (keluaran), outcome (hasil), dan impact (dampak).

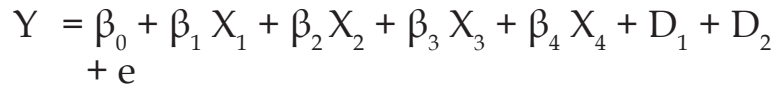

Keterangan:

$\mathrm{Y}=$ Tingkat efektivitas (\%)

$\mathrm{X}_{1}=$ Tingkat pendidikan peminjam (tahun)

$X_{2}=$ Umur peminjam (tahun)

$X_{3}=$ Besaran pinjaman $(\mathrm{Rp})$

$\mathrm{X}_{4}=$ Lama pinjaman (bulan)

$\mathrm{D}_{1}=$ dummy bimbingan/ pengawasan oleh gapoktan

$\mathrm{D}=0$ apabila ada bimbingan/pengawasan

$\mathrm{D}=1$ apabila tidak ada bimbingan/ pengawasan

$\mathrm{D}_{2}=$ dummy jenis usaha

$\mathrm{D}=0$ apabila usaha on farm $\mathrm{D}=1$ apabia usaha off farm

Tabel 2

Aspek Penilaian Kinerja LKM-A

\begin{tabular}{|c|c|c|}
\hline $\begin{array}{c}\text { Aspek } \\
\text { Masukan }\end{array}$ & Kriteria & Skor maksimum \\
\hline \multirow[t]{7}{*}{ Masukan } & & 11 \\
\hline & 1. Kesesuaian dana BLM PUAP & 1 (sesuai BLM PUAP) \\
\hline & 2. Modal keswadayaan & (memiliki kontribusi modal mandiri) \\
\hline & 3. Kelengkapan AD/ART & (memiliki AD/ART) \\
\hline & 4. Badan Hukum LKM-A & (memiliki badan hukum) \\
\hline & 5. Pelatihan & (mengadakan pelatihan) \\
\hline & 6. Sarana dan prasarana LKM-A & (memiliki sarana dan prasarana) \\
\hline \multirow[t]{4}{*}{ Proses } & & 25 \\
\hline & Sosialisasi kepada anggota & 1 (ada sosialisasi) \\
\hline & Pembinaan dan pendampingan & 3 (ada pembinaan dan pemdampingan) \\
\hline & Lama pengajuan & $\begin{array}{l}2 \text { (waktu pengajuan sampai pencairan dana } \\
\text { kurang dari } 2 \text { minggu) }\end{array}$ \\
\hline
\end{tabular}




\begin{tabular}{|c|c|c|}
\hline \multirow{10}{*}{$\begin{array}{c}\text { Aspek } \\
\text { Masukan }\end{array}$} & Kriteria & Skor maksimum \\
\hline & Survei lapang & 2 (ada survei lapang) \\
\hline & Analisis kelayakan usaha & 2 (ada analisis kelayakan usaha) \\
\hline & Pencatatan dan pembukuan & 2 (ada pencatatan dan pembukuan) \\
\hline & Pengendalian penyaluran dana & 2 (ada unit pengendalian penyaluran dana) \\
\hline & Pengawasan pembiayaan & 2 (ada unit pengawasan) \\
\hline & Pelaporan & 3 (ada pelaporan) \\
\hline & Mekanisme insentif dan sanksi & 3 (ada insentif dan sanksi) \\
\hline & Simpanan sukarela & 4 (ada simpanan sukarela) \\
\hline & $\begin{array}{l}\text { Penyelenggaraan Rapat Anggota Tahunan } \\
\text { (RAT) }\end{array}$ & 2 (ada RAT) \\
\hline \multirow[t]{5}{*}{ Keluaran } & & 11 \\
\hline & Penyaluran pinjaman untuk pertanian & $\begin{array}{l}3 \text { (penyaluran utama untuk usaha } \\
\text { pertanian) }\end{array}$ \\
\hline & Penyaluran pinjaman kepada petani miskin & 3 (penyaluran utama untuk petani miskin) \\
\hline & Komulatif penyaluran & 3 (persentase total dana yang disalurkan) \\
\hline & 4.Tingkat pembiayaan bermasalah & 2 (kredit bermasalah kurang dari 5\%) \\
\hline \multirow[t]{4}{*}{ Hasil } & & 4 \\
\hline & Sisa Hasil Usaha (SHU) & $1 \quad$ (ada SHU) \\
\hline & Dana pihak ketiga & 1 (ada dana dari pihak ketiga) \\
\hline & Aset yang dikelola & (aset meningkat) \\
\hline \multirow[t]{5}{*}{ Dampak } & & 4 \\
\hline & Meningkatkan lapangan kerja & 1 (ada peningkatan lapangan kerja) \\
\hline & Meningkatkan skala usaha & 1 (ada peningkatan skala usaha) \\
\hline & Menumbuhkan usaha baru berbasis pertanian & 1 (ada penambahan usaha baru pertanian) \\
\hline & $\begin{array}{l}\text { Menimbulkan ketergantungan terhadap dana } \\
\text { pemerintah }\end{array}$ & $\begin{array}{l}1 \text { (tidak ada ketergantungan pada dana } \\
\text { pemerintah) }\end{array}$ \\
\hline
\end{tabular}

Tabel 3

Klasifikasi Kinerja LKM-A

\begin{tabular}{rlrrrr}
\hline \multirow{2}{*}{ Ket } & \multirow{2}{*}{$\begin{array}{c}\text { Skor } \\
\end{array}$} & Maksimum & \multicolumn{4}{c}{ Skor Kategori } \\
\cline { 3 - 6 } & 55 & Kurang baik & Cukup baik & Baik & Sangat baik \\
\hline Kinerja & 55 & $<38,5$ & $38,51-44,00$ & $44,01-49,5$ & $49,51-55,00$ \\
\hline
\end{tabular}

Sumber : Saleh dkk., (2012)

Untuk mengukur tingkat efisiensi LKM-A, digunakan metode Data Envelopment Analysis (DEA). Analisis logit digunakan untuk menentukan faktor yang mempengaruhi tingkat efisiensi LKM-A.

$$
\begin{aligned}
Y= & \beta_{0}+\beta_{1} X_{1}+\beta_{2} X_{2}+\beta_{3} X_{3}+\beta_{4} X_{4}+\beta_{5} X_{5}+ \\
& \beta_{6} X_{6}+D+e
\end{aligned}
$$

\section{Keterangan:}

$\mathrm{Y}=$ Tingkat efisiensi, $0=$ apabila LKM-A efisien, 1 = apabila LKM-A tidak efisien
$\mathrm{X}_{1} \quad=$ Umur LKM-A (tahun)

$\mathrm{X}_{2}=$ Tingkat pendidikan manajer (tahun)

$X_{3}=$ Waktu pelayanan LKM-A (hari per tahun)

$\mathrm{X}_{4}=$ Jumlah tunggakan (Rp)

$X_{5}=$ Besaran modal mandiri $(R p)$

$X_{6}=$ Besaran bunga (\%)

$\mathrm{D}=$ dummy pendampingan

$\mathrm{D}=0$ apabila tidak pendampingan

$\mathrm{D}=1$ apabila ada pendampingan 


\section{PEMBAHASAN Implementasi PUAP Tiap Kabupaten}

\section{Kabupaten Bantul}

Pelaksanaan PUAP secara umum di Bantul berjalan dengan baik dan terdapat peningkatan rerata jumlah anggota gapoktan dan aset yang dimiliki. Rerata jumlah anggota per gapoktan di Bantul sebelum dana PUAP rata-rata 98 orang kemudian meningkat menjadi 249 orang setelah gapoktan mendapat dana PUAP. Untuk peningkatan aset dari Rp 100 juta menjadi Rp 152 juta. Peningkatan aset disebabkan usaha simpan pinjam yang berjalan baik maupun terdapat pengembangan modal kelompok melalui simpanan pokok dan simpanan wajib/sukarela.

Gapoktan penerima PUAP di Bantul hampir sebagian besar telah berbentuk LKM-A. Hal ini karena kebijakan dari Pemkab Bantul agar gapoktan tersebut harus sudah membentuk LKM-A sejak awal menerima dana. LKM-A di seluruh desa di Bantul telah terbentuk dan memiliki pengelola LKM-A yang terpisah dengan kepengurusan gapoktan, tetapi koordinasi LKM-A berada di bawah gapoktan. Di Bantul sudah terbentuk Asosiasi Gapoktan dan Asosiasi LKM PUAP Bantul (ALKABA). Walaupun begitu, masih ada dua gapoktan yang masih belum membentuk LKM-A, yakni Gapoktan Tani Mulyo (Desa Sriharjo, Imogiri) dan Gapoktan Wukirsari (Desa Wukirsari, Imogiri).

Dalam pelaksanaan PUAP, terlihat mulai ada pembiayaan yang bermasalah dengan indikasi pengembalian dana dari anggota yang terlambat serta usaha anggota yang tidak berkembang. Masalah ini disebabkan tidak ada sanksi yang tegas bagi anggota yang pinjamannya bermasalah. Secara operasional, belum ada pelayanan dari gapoktan yang buka setiap hari dalam waktu sehari penuh. Waktu pelayanan LKM-A untuk peminjaman dan angsuran rutin dilaksanakan sesuai dengan kesepakatan pada saat rapat anggota gapoktan. Sedangkan dari sarana yang tersedia bagi gapoktan masih terdapat keterbatasan sarana, yaitu kepemilikan komputer.

Dalam operasional pinjaman, LKM-A melayani pinjaman baik melalui kelompok tani maupun individu. Pinjaman diberikan LKM-A kepada individu karena lebih mudah mengontrol pinjaman walaupun secara aturan seharusnya LKM-A tidak boleh memberikan pinjaman langsung ke individu. Akan tetapi, LKM-A telah menjalankan arahan tim pembina PUAP kabupaten untuk mengutamakan menyalurkan dana pinjaman kepada kelompok.

\section{Kabupaten Sleman}

Gapoktan penerima PUAP di Sleman merupakan gabungan dari rata-rata 15 kelompok tani dengan jumlah petani pergapoktan sebelum mendapat PUAP sebesar 251 orang yang kemudian bertambah menjadi 282 orang setelah gapoktan mendapat dana PUAP. Peningkatan tersebut menunjukkan dana PUAP telah meningkatkan kesadaran petani untuk berkelompok.

Penerima dana PUAP tahun 2008 dan 2009 di Sleman menunjukkan bahwa sebagian besar masih belum berbentuk LKM-A. Hal ini perlu diperhatikan oleh pemerintah Provinsi DIY dan Kabupaten Sleman untuk mendorong pembentukan LKM-A. Perkembangan aset LKM-A di Sleman berjalan relatif lambat yakni hanya meningkat 19\% dari Rp100 juta menjadi Rp119 juta. Permasalahan ini akibat kemampuan teknis pengelola LKM khususnya dalam menangani administrasi lembaga keuangan yang masih rendah sehingga perlu pembinaan lebih lanjut tentang pengembangan kapasitas lembaga.

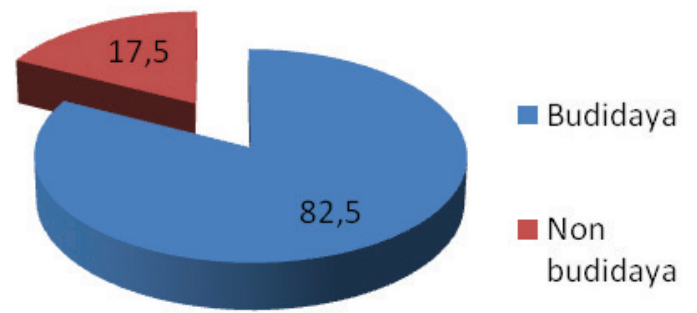

Gambar 1 Alokasi dana PUAP T.A 2008 di Kabupaten Sleman

Sumber : Analisis data sekunder

Pada tahun 2008, alokasi dana PUAP di Sleman yang digunakan untuk usaha budidaya sebesar Rp2.805.900.000 dan untuk usaha nonbudidaya (off farm) sebesar 
Rp594.100.000. Dari keseluruhan dana untuk usaha budidaya, alokasi dana terbesar untuk hortikultura (Rp1.001.400.000), peternakan (Rp 878.850.000), tanaman pangan (Rp840.250.000) serta perkebunan (Rp 85.400.000). Untuk usaha nonbudidaya, alokasi dana terbesar untuk pemasaran hasil pertanian skala mikro (Rp259.450.000), industri rumah tangga pertanian (Rp175.050.000), dan usaha lain berbasis pertanian (Rp159.600.000).
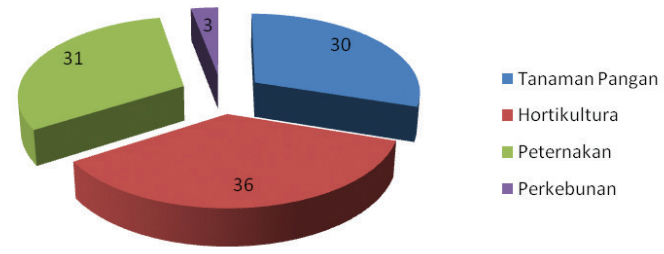

(a)

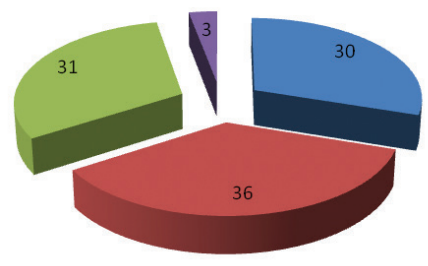

- Tanaman Pangan - Hortikultura Peternakan - Perkebunan

(b)

Gambar 2

Jenis usaha on farm (a) dan off farm (b) gapoktan penerima dana PUAP T.A 2008 di Sleman Sumber: Analisis data sekunder

\section{Kabupaten Kulon Progo}

Rata-rata pergapoktan di Kulon Progo terdiri dari 13 kelompok tani. Jumlah anggota gapoktan sebelum mendapat dana PUAP rata-rata terdiri dari 319 orang, tetapi setelah mendapat PUAP jumlah petani anggota turun menjadi 312 orang. Aset gapoktan di Kulon Progo rata-rata meningkat 23\% dari Rp100 juta menjadi Rp123 juta. Gambaran umum pelaksanaan PUAP di Kulon Progo adalah proses pembentukan LKM-A belum berjalan optimal karena masih ada gapoktan yang masih belum membentuk LKM-A, sedangkan dari segi operasional, terdapat dua permasalahan besar. Pertama, gapoktan kurang siap dalam penumbuhan unit usaha karena

manajemen kelembagaan yang kurang baik. Kedua, perputaran dana di gapoktan terlalu lama sehingga petani anggota ada yang belum menerima dana PUAP.

Total gapoktan yang dibiayai oleh PUAP tahun 2008 di Kulon Progo sebanyak 33 unit atau Rp3,3 miliar dengan alokasi pemakaian untuk usaha budidaya sebesar Rp2.452.720.000,00 dan usaha non budidaya Rp847.288.000,00

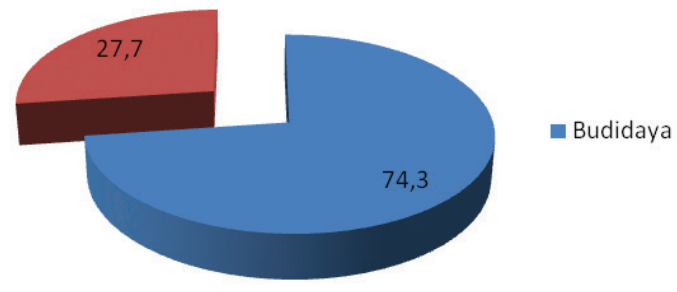

Gambar 3

Alokasi dana PUAP T.A 2008 di Kabupaten Kulon Progo

Sumber : Analisis data sekunder

Usaha budidaya yang ada dialokasikan untuk beberapa jenis subsektor tanaman pangan (Rp484.067.000,00), hortikultura(Rp738.280.000, 00), peternakan (Rp1.201.565.000), perkebunan (Rp28.800.000,00). Untuk usaha non budidaya terdiri atas industri rumah tangga pertanian (Rp148.792. 000,00), pemasaran hasil pertanian skala mikro (Rp422.200.000,00), dan usaha lain berbasis pertanian (Rp276.296.000,00).
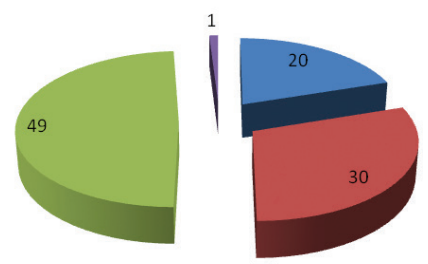

(a)

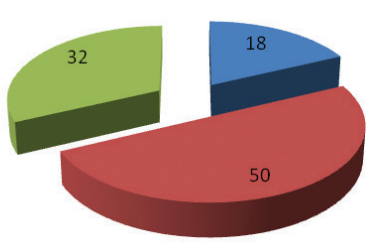

$$
\begin{aligned}
& \text { Industri Rumah Tangga } \\
& \text { Pertanian6 } \\
& \text { Pemasaran Hasil } \\
& \text { Pertanian Skala Mikro } \\
& \text { (bakulan, dlI) } \\
& \text { Usaha lain berbasis } \\
& \text { pertanian }
\end{aligned}
$$

(b)

Gambar 4

Jenis usaha on farm (a) dan off farm (b) gapoktan penerima dana PUAP T.A 2008 di Kulon Progo Sumber : Analisis data sekunder 


\section{Kabupaten Gunungkidul}

Gapoktan penerima PUAP tahun 2008 di Gunungkidul rata-rata terdiri atas 10 kelompok tani. Jumlah anggota pergapoktan mengalami peningkatan $50 \%$ dari sebelum mendapat dana PUAP, yaitu dari 113 orang menjadi 189 orang. Aset gapoktan di Gunungkidul secara keseluruhan meningkat dari Rp100 juta menjadi Rp117 juta dengan peningkatan aset terbesar adalah gapoktan Harapan Jaya di Desa Putat Patuk.

Perkembangan PUAP di Kabupaten Gunungkidul berjalan lambat dilihat dari perkembangan modal. Hal ini disebabkan kelembagaan gapoktan yang perlu diperkuat serta kegiatan bisnis yang belum beroperasi dengan baik. Penguatan kelembagaan perlu segera dilakukan karena SDM belum mampu mengelola keuangan dengan baik serta belum semua gapoktan melakukan penyertaan modal anggota (belum ada simpanan pokok/ wajib). Penyaluran dana oleh gapoktan lebih bersifat pemerataan kepada anggota bukan didasari atas skala usaha anggota sehingga anggota yang sangat membutuhkan akan tetap mengalami kekurangan modal.

Pemanfaatan dana PUAP tahun 2008 di Gunungkidul dialokasikan untuk usaha budidaya (on farm) Rp2.109.550.000,00 dan non budidaya (off-farm) Rp1.390.050.000,00 Alokasi dana PUAP untuk usaha budidaya di Gunungkidul tahun 2008 terdiri atas tanaman pangan (Rp57.000.000,00), hortikultura (Rp20.000.000,00), peternakan (Rp2.004.550. 000,00), dan perkebunan (Rp8.000.000,00). Rincian untuk usaha nonbudidaya antara lain industri rumah tangga pertanian ( $\mathrm{pp}$ 26.500.000,00), pemasaran hasil pertanian skala mikro (Rp46.250.000,00), dan usaha lain berbasis pertanian (Rp 117.700.000,00).

Pelaksanaan PUAP tahun 2009 berjalan dengan baik dimana aset rata-rata gapoktan mengalami kenaikan dari Rp100 juta menjadi Rp115,6 juta dengan penambahan jumlah petani anggota per gapoktan naik sekitar $80 \%$ dari 112 orang menjadi 195 orang. Hal serupa juga terjadi pada tahun 2010, dimana jumlah petani anggota pergapoktan naik cukup signifikan dari 165 orang menjadi 270 orang dengan aset pergapoktan meningkat dari Rp100 juta menjadi Rp115,7 juta. Untuk tahun 2011, aset pergapoktan naik lebih cepat, yaitu dari Rp100 juta menjadi Rp121,5 juta serta anggota petani pergapoktan naik hampir $200 \%$ dari 83 orang menjadi 162 orang.

\section{Efektivitas Lembaga Keuangan Mikro Agribisnis}

Persentase petani penerima dana PUAP di Daerah Istimewa Yogyakarta (DIY) yang memperoleh informasi dana dari pengurus gapoktan sebanyak 55,55\% sedangkan 25,64\% dari kelompok tani serta sisanya memperoleh informasi dari sumber lain. Alokasi dana di tingkat petani yakni $63,32 \%$ untuk usaha on farm, 23\% usaha off farm, dan 13,68\% untuk kegiatan konsumtif. Alasan utama petani memanfaatkan dana PUAP karena prosedur yang mudah, bunga rendah, dan tanpa agunan. Dalam melakukan pinjaman, 60,68\% petani melakukan pinjaman melalui kelompok serta $51,28 \%$ nya dikenakan biaya administrasi.

Jumlah petani yang meningkat pendapatannya karena dana PUAP sebesar 23,08\% dari keseluruhan peminjam dana dengan rata-rata peningkatan pendapatan perpetani sebesar $8,68 \%$ serta membuka usaha baru bagi sekitar 16,24\%. Dari seluruh petani yang meminjam dana PUAP, sebesar 70,08\% petani tidak meminjam kepada kreditur lain setelah menerima dana PUAP.

Secara makro, program PUAP mampu menurunkan kemiskinan karena pendapatan petani meningkat di atas standar kemiskinan nasional (standar nasional 1 US\$ per kapita perhari), yaitu mampu menurunkan kemiskinan sebesar 6,06\% (8.902 jiwa) di Kabupaten Bantul, 16,67\% (21.844 jiwa) di Kabupaten Sleman, 0\% (0 jiwa) di Kabupaten Kulon Progo, dan 11,43\% (16.996 jiwa) di Kabupaten Gunungkidul serta secara keseluruhan mampu menurunkan kemiskinan sebesar 7,00\% (37.828 jiwa) dari seluruh penduduk miskin di DIY.

Berdasarkan hasil wawancara petani, masalah terkait dana PUAP antara lain (1) Modal yang diperoleh terlalu kecil, (2) Petani kurang cakap dalam berwirausaha, dan (3) Sistem pengendalian pinjaman dari pengurus 
masih lemah sehingga banyak pinjaman yang bermasalah dan banyak petani yang tidak mendapat dana bergulir.

\section{Tabel 4}

Hasil Uji Regresi Faktor yang Mempengaruhi Efektivitas Pinjaman

\begin{tabular}{lll}
\hline \multicolumn{1}{c}{ Variabel } & \multicolumn{1}{c}{ Koefisien } & \multicolumn{1}{c}{ Sig. } \\
\hline Konstanta & -6.450 & 0.803 \\
Tingkat pendidikan & 1.185 & 0.247 \\
Usia & -0.202 & 0.479 \\
Besar pinjaman & $-3.030 \mathrm{E}-6$ & 0.102 \\
Lama pinjaman & 1.782 & $0.065 * *$ \\
Bimbingan & -1.345 & 0.836 \\
Jenis usaha & 14.117 & $0.045 *$ \\
\hline
\end{tabular}

Prob. Chi-Square 0,7013 Adj R Squared 0,6586

Prob. Jarque Bera 0,6831 Prob. (F-statistic) 0,0000

Sumber : Analisis data primer (2012)

Keterangan :

* signifikan pada taraf nyata $5 \%$

** signifikan pada taraf nyata $10 \%$

Tabel 4 menunjukkan hasil analisis regresi memiliki varian yang sama atau tidak mengalami heteroskedastisitas (probabilitas Chi-Square $>0,1$ ) dan terdistribusi normal (probabilitas Jarque Bera $>0,1$ ). Seluruh variabel independen yang digunakan dalam regresi mempengaruhi variabel dependen dengan $65,86 \%$ variasi variabel independen mampu menjelaskan variasi variabel dependen.

Hasil analisis regresi menunjukkan efektivitas program PUAP di tingkat petani dipengaruhi lama pinjaman dan jenis usaha. Apabila lembaga pelaksana memberikan waktu lebih panjang kepada petani dan memperhatikan jenis usaha peminjam maka efektivitas PUAP akan meningkat. Jenis usaha off farm akan mampu meningkatkan efektivitas PUAP. Akan tetapi, kuantitas usaha off farm masih sedikit, maka perlu dilakukan pengembangan jenis usaha tersebut.

\section{Kinerja dan Tingkat Efisiensi Lembaga Keuangan Mikro Agribisnis}

Pelaksanaan program PUAP di DIY untuk kinerja input mencakup dana PUAP yang telah masuk ke rekening Gapoktan dan sesuai dengan ketentuan dimana 96,7\% LKM-A di DIY mendapat dana PUAP tepat Rp100 juta tanpa ada potongan biaya administrasi sedangkan 3,3\% LKM-A menerima dana kurang dari Rp100 juta yakni LKM-A di Gunungkidul. Selain itu, sebanyak 70,00\% LKM-A di DIY mulai memiliki modal swadaya berupa simpanan pokok, wajib, dan sukarela dengan besaran nominal simpanan bervariasi. Pengamatan aspek organisasi menunjukkan seluruh gapoktan telah memiliki AD/ART, tetapi sebanyak $15,00 \%$ belum lengkap serta belum sepenuhnya gapoktan mematuhi aturan tersebut saat menjalankan kegiatan operasional. Faktor penghambat terbesar untuk kinerja input adalah sebagian besar LKM-A di DIY belum berbadan hokum, yaitu mencapai $91,70 \%$, sedangkan LKM-A yang mengajukan status badan hukum ada 5,00\% serta 3,30\% merupakan LKM-A yang telah berbadam hukum. Sebanyak 86,33\% LKM-A pernah mendapatkan pelatihan keuangan mikro dari Kementerian Pertanian. Untuk kondisi sarana dan prasarana LKM-A sebagian besar telah ada, tetapi masih belum lengkap. Penggunaan dana PUAP oleh petani ada yang tidak sesuai dengan RUA (Rencana Usaha Anggota) karena kurangnya pengawasan dari LKMA atau penyuluh pendamping sehingga dana digunakan petani untuk keperluan lain. Bahkan dari hasil evaluasi, sebanyak $39 \%$ petani menggunakan dana PUAP bukan untuk kegiatan produktif, tetapi digunakan memenuhi kebutuhan sehari-hari. Ada pengelola yang tidak sesuai dengan persyaratan wajib seperti yang ditetapkan Kementerian Pertanian yaitu minimal DIII. Hasil evaluasi lapangan menunjukkan bahwa banyak pengurus LKM-A yang berpendidikan di bawah DIII.

Untuk pelaksanaan tahapan proses PUAP di DIY mencakup gapoktan yang telah melakukan sosialisasi kepada anggota mengenai dana PUAP, tetapi banyak petani yang kurang memahami maksud dan tujuan program PUAP. Penyuluh pendamping (PPL) dan penyelia mitra tani (PMT) telah melakukan pendampingan yakni 38,33\% LKM-A mendapat pendampingan lebih dari $12 \mathrm{kali}$, tetapi menurut LKM-A masih tidak optimal untuk 
menyelesaikan masalah. Sebanyak 51,67\% LKM-A mampu menyalurkan dana kurang dari satu atau dua minggu setelah anggota mengajukan pinjaman, sedangkan 40,00\% membutuhkan waktu kurang lebih dua minggu sampai satu bulan serta sisanya menyalurkan dana lebih dari satu bulan. Sebagian besar LKM-A mengadakan analisis kelayakan dan survei terhadap calon peminjam, tetapi banyak pula LKM-A yang tidak melakukan karena menyalurkan pinjaman atas dasar mengenal trackrecord calon peminjam. Kegiatan pencatatan dan pembukuan rutin dilakukan oleh LKM-A, tetapi masih belum lengkap. Sebagian besar LKM-A telah melakukan pengendalian dan pengawasan pembiayaan walaupun masih banyak kredit macet. Mekanisme pemberian insentif telah dilakukan 60\% LKM-A, yaitu dengan pemberian SHU bagi nasabah yang tepat waktu dalam mengangsur. Mekanisme sanksi juga mulai diterapkan, tetapi belum diterapkan secara tegas. LKM-A yang mampu menggalang simpanan sukarela masih sangat kecil, yaitu 35\%. Pelaksanaan RAT LKM-A dilaksanakan tepat waktu setiap bulan Maret.

Pelaksanaan indikator output PUAP di DIY mencakup LKM-A yang menyalurkan lebih dari $80 \%$ dana PUAP untuk usaha pertanian ada $40 \%$ LKM-A, sedangkan LKM-A yang menyalurkan $50-80 \%$ dana PUAP untuk usaha pertanian ada $43,33 \%$ serta LKM-A yang menyalurkan kurang dari 50\% dana PUAP untuk usaha pertanian ada 16,67\% LKM-A. Jumlah LKM-A yang menyalurkan lebih dari $50 \%$ dana untuk petani miskin ada 51,67\% LKM-A serta ada $6,67 \%$ tidak menyalurkan dana PUAP untuk petani miskin sedangkan sisanya menyalurkan kurang dari $50 \%$ dana untuk petani miskin. Seluruh LKM-A menyalurkan lebih dari 50\% bahkan lebih dari $100 \%$ dana yang ada untuk simpan pinjam anggota, dan jumlah kredit bermasalah dengan persentase lebih dari 5\% terdapat pada $70 \%$ LKM-A, sedangkan yang mengalami kredit bermasalah kurang dari 5\% mencapai 30\% LKM-A.

Pelaksanaan indikator outcome PUAP di DIY mencakup SHU bagi anggota sudah cukup besar yakni mencapai 65,00\%, sedangkan sisanya disalurkan sebagai modal usaha anggota. LKM-A yang mampu menggalang dana dari pihak ketiga hanya $10,00 \%$. Aset dana yang dikelola LKM-A cukup besar, yaitu antara Rp100 juta sampai Rp150 juta bahkan ada yang lebih dari Rp150 juta.

Pelaksanaan PUAP di DIY telah memberikan dampak antara lain: Peningkatan lapangan pekerjaan dan usaha baru bagi 88,33\% LKM-A serta dana PUAP juga menyebabkan ketergantungan terhadap dana pemerintah mencapai 8,33\% LKM-A sedangkan sisanya tidak tergantung dana pemerintah.

Untuk penilaian kinerja LKM-A, maka dapat diklasifikasikan sebagai berikut: (1) Kinerja LKM-A yang berkategori kurang baik (nilai $<38,5$ ) sebanyak 50,00\% yang sebagian besar ada di Kulon Progo. (2) Kinerja LKM-A yang berkategori cukup baik (nilai 38,51-44,00) sebanyak $38,33 \%$ yang sebagian besar ada di Bantul, Kulon Progo, dan Gunungkidul. (3) Kinerja LKM-A yang berkategori baik (nilai 44,01-49,5) sebanyak 11,67\% yang sebagian besar ada di Bantul, dan (4) Tidak ada LKM-A yang berkategori kinerja sangat baik.

LKM-A berkategori kurang baik memiliki masalah utama di bagian input, belum berbadan hukum, di bagian proses yaitu simpanan sukarela masih rendah, di bagian output yaitu tingkat pinjaman bermasalah cukup tinggi serta di bagian outcome yaitu dana tambahan dari pihak ketiga cukup rendah. Permasalahan tersebut terjadi hampir di semua LKM-A, terutama di Kulon Progo, sehingga banyak LKM-A dalam kategori kurang baik. Sebagian besar LKM-A di Kulon Progo menyalurkan seluruh modal untuk usaha budidaya sehingga perputaran dana berjalan lambat.

Kinerja LKM-A di Bantul sebagian besar termasuk baik dan cukup baik karena penerapan kebijakan pemerintah daerah yang mewajibkan gapoktan penerima dana PUAP sudah membentuk LKM-A di tahun pertama. Hal ini mampu mendorong kinerja dan manajemen keuangan LKM-A yang lebih profesional dengan sistem operasional yang baik.

Apabila kinerja LKM-A ditinjau berdasarkan tahun anggaran PUAP, maka dapat diklasifikasikan sebagai berikut: (1) Untuk LKM-A 
penerima dana PUAP tahun anggaran 2008 menunjukkan kinerja 50\% kurang baik, 35,71\% cukup baik, 14,29\% berkategori baik serta tidak ada LKM-A berkategori sangat baik, (2) Untuk LKM-A penerima dana PUAP tahun anggaran 2009 menunjukkan kinerja 50\% kurang baik, $35,71 \%$ cukup baik, $14,29 \%$ berkategori baik serta tidak ada LKM-A berkategori sangat baik, (3) Untuk LKM-A penerima dana PUAP tahun anggaran 2010 menunjukkan kinerja $53,33 \%$ kurang baik, 40,00\% cukup baik, 6,67\% berkategori baik serta tidak ada LKM-A berkategori sangat baik, dan (4) Untuk LKM-A penerima dana PUAP tahun anggaran 2011 menunjukkan kinerja 47,06\% kurang baik, $41,18 \%$ cukup baik, $11,76 \%$ berkategori baik serta tidak ada LKM-A berkategori sangat baik.

Berdasarkan analisis tahun penerimaan PUAP, sebagian besar LKM-A termasuk kategori kurang baik. Untuk kategori cukup baik, LKM-A penerima dana tahun 20082011 memiliki variasi yang sama. Perbedaan cukup jelas terjadi untuk kategori baik dimana LKM-A penerima PUAP tahun 2008 dan 2009 cukup banyak yang termasuk kategori ini dibandingkan penerima PUAP tahun 2010 dan 2011. Akan tetapi, secara keseluruhan dapat disimpulkan bahwa kinerja tidak ditentukan tahun ketika LKM-A menerima dana PUAP.

Hasil analisis efisiensi LKM-A di DIY dengan metode DEA menunjukkan bahwa 76,32\% LKM-A efisien dalam melaksanakan operasional kegiatan sedangkan 23,68\% tidak efisien. Apabila ditinjau berdasarkan tahun anggaran PUAP, maka dapat diperoleh hasil yaitu (1) Penerima dana PUAP tahun anggaran 2008 terdapat $100 \%$ LKM-A yang telah efisien, (2) Penerima dana PUAP tahun anggaran 2009 terdapat $85,71 \%$ LKM-A yang telah efisien sedangkan 14,29\% tidak efisien, (3) Penerima dana PUAP tahun anggaran 2010 terdapat $73,33 \%$ LKM-A yang telah efisien sedangkan 26,67\% tidak efisien, dan (4) Penerima dana PUAP tahun anggaran 2011 terdapat 82,35\% LKM-A yang telah efisien sedangkan 17,65\% tidak efisien.

Tabel 5 menunjukkan hasil analisis yang memengaruhi efisiensi LKM-A dimana nilai statistik likelihood ratio $(18,234)$ lebih besar dari nilai tabel chi square pada taraf $5 \%(14,07)$ dan nilai $R^{2}$ McFadden 0,1758 atau $17,58 \%$ variasi semua variabel independen mampu menjelaskan variasi variabel dependen. Dengan analisis logit ini, maka variabel dummy pada variabel dependen dan independen tidak menimbulkan permasalahan heteroskedastisitas.

Hasil analisis menunjukkan tingkat efisiensi LKM-A dipengaruhi besar modal mandiri dan dummy pendampingan. Semakin besar modal mandiri yang berhasil dikumpulkan oleh LKM-A maka tingkat efisiensi LKM-A akan semakin meningkat pula. Untuk dummy pendampingan berpengaruh terhadap efisiensi dengan semakin intensif pendampingan dari tim teknis PUAP, maka efisiensi LKM-A akan meningkat pula. Hasil ini juga selaras dengan penelitian (Sandyatma dan Hariadi, 2012) yang menyatakan bahwa pendampingan akan memperbaiki kinerja lembaga pertanian.

Tabel 5

Hasil Analisis Regresi Faktor yang Mempengaruhi Tingkat Efisiensi LKM-A

\begin{tabular}{lll}
\hline \multicolumn{1}{c}{ Variabel } & \multicolumn{1}{c}{ Koefisien } & \multicolumn{1}{c}{ Prob. } \\
\hline C & -1.186584 & 0.750 \\
Usia LKM-A & -0.576688 & 0.222 \\
Pendidikan & 0.028479 & 0.913 \\
Waktu Pelayanan & 0.002648 & 0.660 \\
Tunggakan & $1.02 \mathrm{E}-08$ & 0.657 \\
Modal Mandiri & $1.30 \mathrm{E}-08$ & $0.035^{*}$ \\
Bunga & 0.163364 & 0.177 \\
Dummy Pendampingan & 2.456483 & $0.059^{* *}$ \\
\hline LR statistic (7 df) & 18,234261 & \\
\hline McFadden R-squared & 0,175825 & \\
\hline
\end{tabular}

Sumber : Analisis data primer (2013)

Keterangan :

* signifikan pada taraf nyata $5 \%$

** signifikan pada taraf nyata $10 \%$

\section{SIMPULAN}

Program PUAP berdampak pada peningkatan pendapatan petani; mengurangi jumlah penduduk miskin; meningkatkan jumlah anggota, simpanan dan aset gapoktan; lapangan kerja akan meningkat dan petani tidak meminjam dana ke lembaga lain. Akan tetapi, pelaksanaan PUAP juga mengalami beberapa masalah di antaranya terdapat 
penyimpangan penyaluran dana PUAP langsung ke individu (seharusnya kepada kelompok tani), penggunaan dana PUAP yang tidak sesuai RUA, ada petani yang menunggak pembayaran (kredit macet), sebagian besar LKM-A belum berbadan hukum, kapasitas SDM pengelola masih rendah serta meningkatkan ketergantungan petani terhadap bantuan pemerintah. Faktor lama pinjaman dan jenis usaha petani berpengaruh terhadap efektivitas program PUAP di DIY. Penilaian kinerja LKM-A di DIY dapat diklasifikasikan LKM-A berkategori kurang baik sebanyak $50,00 \%$, kategori cukup baik sebanyak 38,33\%, kategori baik sebanyak $11,67 \%$, dan tidak ada LKM-A yang berkinerja sangat baik. Efisiensi LKM-A dipengaruhi oleh besar modal mandiri dan adanya pendampingan dari pemerintah.

Aktivitas yang diperlukan untuk perbaikan PUAP mencakup (1) Pembinaan dan pengawasan terhadap LKM-A, (2) Pengendalian kredit macet dan insentif kredit lancar nasabah, (3) Pemilihan jenis usaha LKM-A, dan (4) Mendorong LKMA untuk berbadan hukum

\section{DAFTAR PUSTAKA}

Dwimanur, K. dan H. Wibowo. 2014. "Strategi Pembentukan Lembaga Keuangan Mikro Agribisnis (LKMA) Pasca Program Pengembangan Usaha Perdesaan (PUAP) di Kabupaten Kuningan". Jurnal Ekonomi dan Perbankan Syariah 2(1): 26-52.

Erna, K., I.K. Kriya, dan N.N. Yulianthini. 2014. "Pengaruh Dana Pengembangan Usaha Agribisnis Perdesaan terhadap Pendapatan Anggota Kelompok Simantri". Jurnal Jurusan Manajemen 2(1): 1-8.

Iski, N., N. Kusnadi, dan Harianto. 2016. "Pengaruh Kredit terhadap Pendapatan Petani Kopi Arabika di Kabupaten Aceh Tengah Provinsi Aceh". Jurnal Manajemen dan Agribisnis 13(2): 132-144.

Ismanto, H. dan T. Diman. 2014. "Analisis Efektivitas Pemberian Pinjaman Program Pembiayaan UMKM Oleh
Koperasi". Jurnal Economia 10(2): 148-164.

Martiana, Hasudungan, dan Jufri. 2012. "Monitoring dan Evaluasi Program Pengembangan Usaha Agribisnis Perdesaan di Kecamatan Pancur Batu Kabupaten Deli Serdang". Jurnal Ilmu-ilmu Agribisnis 1(1): 1-13.

Pangestika, C.R., S. Sjamsuddin. dan Suwondo. 2015. "Implementasi Program Pengembangan Usaha Agribisnis Perdesaan (PUAP) (Studi Kasus Gapoktan Tri Langgeng Desa Ngompro Kecamatan Pangkur Kabupaten Ngawi)". Jurnal Administrasi Publik 3(5): 752-757.

Rahayu, L. 2015. "Aksesibilitas Petani Bawang Merah terhadap Lembaga Keuangan Mikro Sebagai Sumber Pembiayaan". AGRARIS: Journal of Agribusiness and Rural Development Research 1(1): 52-60.

Rahayuningsih, A. 2013. “Efektifitas Penggunaan Pinjaman Bergulir BKM PNPM Mandiri Perkotaan pada Masyarakat Kecamatan Jepara Tahun 2011". Jurnal Dinamika $\mathcal{E}$ Bisnis 10(1) : 81-94.

Saleh, Y. J. H.Mulyo, dan L. R.Waluyati. 2012. "Efisiensi Lembaga Keuangan Mikro Agribisnis Gabungan Kelompok Tani dalam Pengembangan Usaha Agribisnis Perdesaan : Studi Kasus di Kabupaten Bantul Tahun 2012". Jurnal Agro Ekonomi 30(2): 129-144.

Sandyatma, Y.H. dan S.S. Hariadi. 2012. "Partisipasi Anggota Kelompok Tani dalam Menunjang Efektivitas Gapoktan pada Kegiatan Penguatan Lembaga Distribusi Pangan Masyarakat di Kabupaten Bogor". Kawistara 2(3): 238-251.

Suandi, Y. Damayanti, dan Yulismi. 2012. "Model Pengembangan Usaha Agribisnis Perdesaan pada Usahatani Padi Sawah di Kecamatan Sekernan Kabupaten Muaro Jambi Provinsi 
Jambi". Jurnal Penelitian Universitas Jambi Seri Humaniora 14(2): 25-34.

Supanggih, D. dan S. Widodo. 2013. “Aksesbilitas Petani terhadap Lembaga Keuangan (Studi Kasus pada Petani di Desa Sidodadi Kecamatan Sukosewu Kabupaten Bojonegoro)". Jurnal Agriekonomika 2(2): 163-173.

Supardi, P.N., K.B. Susrusa, dan I.W. Budiasa. 2015. “Tingkat Keberhasilan Program Pengembangan Usaha Agribisnis Perdesaan di Kabupaten Ende Provinsi Nusa Tenggara Timur". Jurnal Manajemen Agribisnis 3(2): 121133.

Supriatna, A. 2012. “Perkembangan Lembaga Keuangan Mikro Agribisnis (LKMA) dan Adopsi Teknologi Kentang pada Pengembangan Usaha Agribisnis
Perdesaan (PUAP) (Studi Kasus di Kabupaten Solok, Sumatera Barat)". Agrin 16(2): 101-116.

Utami, R.A. 2015. “Analisis Keberlanjutan dan Pola Pengembangan Co-operative Entrepreneurship Lembaga Keuangan Mikro Agribisnis (LKM-A)". Jurnal Ilmu Sosial dan Ilmu Politik 19(1): 65-77.

Zanzes, G.F., I.W. Suwendra, dan G.P.A.J. Susila. 2015. "Analisis Efektivitas Program Usaha Agribisnis Perdesaan (PUAP) serta Dampaknya terhadap Tingkat Pendapatan (Studi Kasus pada Gabungan Kelompok Tani Wahana Sari)". Jurnal Bisma Universitas Pendidikan Ganesha Jurusan Manajemen 3(1): 1-10. 